\title{
Gamma Rays Mediated Mutagenesis of Super Koji (Aspergillus oryzae) to enhance the Thermostability and Production of CMCases: Process Scale-up at Pilot Level
}

\section{Neelam Zeb}

Pakistan Institute of Engineering and Applied Sciences

Muhammad Hamid Rashid ( $\sim$ hamidcomboh@gmail.com )

Pakistan Institute of Engineering and Applied Sciences https://orcid.org/0000-0003-2759-0533

\section{Bushra Aleem}

Pakistan Institute of Engineering and Applied Sciences

\section{Fariha Iftikhar}

Pakistan Institute of Engineering and Applied Sciences

Anam Saqib

Pakistan Institute of Engineering and Applied Sciences

Hazrat Ali

Pakistan Institute of Engineering and Applied Sciences

Hassan Sher

Pakistan Institute of Engineering and Applied Sciences

\section{Saif ur Rehman}

Pakistan Institute of Engineering and Applied Sciences

\section{Bilqees Fatima}

Pakistan Institute of Engineering and Applied Sciences

\section{Waheed S Khan}

Pakistan Institute of Engineering and Applied Sciences

\section{Research article}

Keywords: strain improvement, clearance index (Cl), 2-deoxy D-glucose, growth kinetics, half-life, Aspergillus oryzae

Posted Date: June 21st, 2019

DOI: https://doi.org/10.21203/rs.2.10510/v1 
License: (c) (i) This work is licensed under a Creative Commons Attribution 4.0 International License. Read Full License 


\section{Abstract}

Background The $\beta-1$, 4-endoglucanase belongs to cellulases group of enzymes, which hydrolyse $\beta-1,4$ glucosidic bonds in the naturally occurring cellulose or synthetic Carboxymethyl cellulose CMC thus also named as CMCase. Endoglucanase from Aspergillus oryzae is favoured in food and feed industries due to its GRAS (generally regarded as safe) status and for relatively stable enzymes production. Results Current report is novel as it deals with the development of super Koji strain having hyper production of thermostable CMCases. Hence, the potent Koji's mutant, hyper producer of thermostable endoglucanase was screened from the available mutants stock (Total $=52$ variants), which was generated through gamma rays treatment of Super Koji strain (A. oryzae cmc1). Initially, seventeen (17) mutants hyper producer of CMCases were selected based on the basis of clearance zone index $(\mathrm{Cl})$ on the plates supplemented with 1\% CMC. Afterwards, six mutants resistant to 2-deoxy-D-glucose were selected having enhanced CMCase production. Mutants' next screening was on submerged CMCase production. Potent mutant 60(5) having $60 \mathrm{kRad}$-rays exposure showed 3.6 folds hyper CMCase production $(6.02 \mathrm{U} \mathrm{ml}-1)$. The half-life of endoglucanse produce of A. oryzae mutant 60(5) was $29.42 \mathrm{~min}$ and $14.8 \mathrm{~min}$ at $55 \llbracket \mathrm{C}$ and $60 \llbracket \mathrm{C}$, respectively, which was 4 folds higher than the control at $60 \bowtie \mathrm{C}$. The LC-MS analysis showed that A. oryzae mutant 60(5) does not produce aflatoxins. Field Emission Scanning Electron Microscopy (FESM) of mutated Koji depicted that gamma radiations enhanced the stiffness of fungal mycelia. Kinetics of CMCase production by mutant $60(5)$ in $10 \mathrm{~L}$ and $200 \mathrm{~L}$ fermenter was as: CMCase $=913 \mathrm{U}$ dl-1 \& $821 \mathrm{U}$ dl-1; Specific growth $(\mu)=0.064 \& 0.082$ hours; Cell mass doubling time $(\mathrm{td})=10.71 \& 8.42$ hours; Yield coefficient with respect to cell mass $(Y p / x)=59 \mathrm{Ug}-1$ \& $89 \mathrm{U}$ g-1 and Specific rate of CMCase production $(\mathrm{qp})=3.84 \mathrm{Ug}-1 \mathrm{~h}-1 \& 7.37 \mathrm{Ug}-1 \mathrm{~h}-1$ respectively. Conclusion We concluded, $\mathrm{y}$-rays induced potent mutations in mutant 60(5) resulting in hyper production of thermostable endoglucanase, which can withstand harsh industrial conditions. Hence, has great potential for applications in food \& feed and other industrial processes.

\section{Background}

Enzymes are the efficient natural biocatalysts offering many industrial applications with the advancements in protein engineering and employed in bioprocesses by replacing chemical catalysts [1]. Due to advancements in recombinant DNA technology and modifications of enzymes structures through engineering and computational design approaches the applications of enzymes are now offering in commercial, academic and industrial sectors [2]. Enzymes are proteinaceous macromolecules, highly specific in nature, determined by the catalytic sites present deep inside the hydrophobic pockets and accelerated the rate of reaction up to $10^{17}$ factor by lowering energy of activation [3]. More than 4000 types of enzymes are produced by living organisms among which 200 enzymes are produced by microorganisms. Till now more than 20 different types of microbial enzymes are reported to produce at large scale [2]. Microbial enzymes produced on commercial scales for various industrial applications are comparatively considered superior because of more stability than plants and animals enzymes and higher yield in short time by fermentation $[4,5]$. 
Fungal cellulases are group of hydrolytic enzymes composed of three subclasses; $\beta$-1,4-endoglucanases, cellobiohydrolases or exoglucanases and $\beta$-glucosidases. Cellulose is hydrolysed into glucooligosaccharides by endoglucanases and cellobiohydrolases, which are further hydrolyzed by $\beta$ glucosidases [6]. Endoglucanases also known as "CMCases" hydrolyse amorphous cellulose more actively than crystalline cellulose [7]. CMCases can even hydrolyse the intermediate product cellodextrin into glucose and cellubiose [8].

Endoglucanases are the largest groups of enzymes constituting third group of enzyme world-wide and used commercially for more than 30 years [9]. Cellulases are used in various industrial applications such as alcohol production, fruits and vegetables extraction, brewing and malting [10], animal feed, food, paper and pulp, textile and laundry industries, agriculture and even for academic and research purposes [11]. The demand for cellulases is increasing day by day due to its applications in production of second generation biofuels and previous studies have reported that about $20 \%$ of world enzyme market was constituted by cellulolytic enzymes [12]. Cellulases play key role in livestock feed industry. The animal feeds usually contain lignocellulosic material such as cellulose, hemicellulose and lignin that have low proteins and high fiber contents and low digestibility. Therefore by treating and supplementing the animal feeds with cellulases will breakdown the bonds in lignocellulosic material and will improve the digestibility and feed utilization, which will intern improve milk and meat production in dairy animals [13].

Cellulose is highly crystalline structure composed of glucose units arranged in linear chain by $\beta-1,4$ bond, which is used in chemicals production and is abundant source of biofuels [14]. The enzymatic degradation of cellulose is more cost effectiveness, economical and produces low pollution [15]. Microbes can produce cellulases but fungi are comparatively more potent producers than bacteria. Fungal cellulases are usually preferred because of higher production rate and comparatively more thermostable that can withstand the harsh industrial conditions [16]. Various fungi like Trichoderma, Aspergillus, Penicillium, Humicola, etc are industrially important producers of cellulases [17].

Aspergillus genus is known for the hyper production of cellulases and its species like $A$. oryzae, $A$. niger, $A$. terrus, $A$. niveus and $A$. ochraceus are reported as the best producers [18]. The $A$. oryzae and $A$. niger are important potent endoglucanase producers, usually employed in various industrial and biotechnological applications. They also produce other enzymes for the degradation of plant polysaccharides such as pectin, xyloglucan, xylan and galactomannan $[19,20]$. The Koji $(A$. oryzae) has immense potential to secrete proteins extra cellularly and has GRAS (Generally Recognized as Safe) status; hence Japanese are using it for more than 1000 years to make the fermented foods [21]. Due to easy optimization of temperature and $\mathrm{pH}$ and handling, submerged fermentation is used for cellulase and other enzymes production, while solid state fermentation is cost effective with high yield [22, 23].

Cellulase production can be further enhanced by strain improvement through genetically modifying the microbial strains via different techniques, which has gained much importance [24]. Commercial production of cellulases is enhanced by genetic modifications and random mutagenesis of the parental strains [25]. Moreover, the molecular cloning of cellulases genes or increasing copy number also have 
great impact on degradation of cellulosic material and production of high quality value-added products [26]. Bacterial cellulosome or Cellulase system is more complex than fungal cellulases, which is composed of two domains; "catalytic domain" and "Cellulose binding domain". Both CD and CBD are linked to one another by short polylinker region [27]. This structure facilitates the binding of both substrate (even insoluble) and enzyme. But mostly endoglucanases are devoid of cellulose binding domains and they hydrolyse the substrate through swelling. Fungi can be improved by simultaneous treatment of chemical mutagens and radiations and it is found that sequential treatment of fungus with Ultraviolet radiations (UV), N-methyl-N-nitro-N-nitrosoguanidine (NTG), $\mathrm{Y}$-rays (Co source) has improved the production of cellulases [24]. Similarly, [28] formed mutant fungi for the overproduction of CMCase and FPAse by simultaneous treatment with NTG with ethidium bromide and UV, NTG and ethidium bromide.

We developed catabolite resistant Koji strain (Aspergillus oryzae cmc-1) through cloning of cmc-1 gene from Aspergillus aculeatus, which is hyper producer of endoglucanase [29]. But unfortunately half-life of the Koji's endoglucanase was only $3.7 \mathrm{~min}$ at $56^{\circ} \mathrm{C}$ [30]. The demand for industrial enzymes is increasing along with their usage in poultry. In poultry sector the Koji's endoglucanase can only be applied through drinking water because the enzyme does not have sufficient stability to be mixed in the poultry feed at the pelleting stage, which operates at about $80^{\circ} \mathrm{C}$. Therefore, to withstand harsh industrial conditions it is desired to improve the thermostability of the enzyme. Recently, we have developed a main stock of 52 Koji mutants through gamma rays treatment, which are resistant to $1 \%(\mathrm{w} / \mathrm{v})$ Triton X-100 and a five step screening process has been established to dig out the potent strains hyper producer of thermostable aamylases [31]. There is no enzyme producing industry in Pakistan; therefore, we have to search for the potent hyper producer microbes to reduce the dependency on imported enzymes. The envisaged study is based on screening of the mutant's stock to find potent Koji mutants, hyper producer of thermostable CMCases. Hence, the study is novel as it deals with the generation of potent food grade Koji mutants through $y$-rays treatment having higher production of endoglucanases with enhanced thermostability.

\section{Results}

The super Koji ( $A$. oryzae) and 52 mutants obtained by random mutagenesis were screened through a four-step screening process developed for the screening of hyper producer thermostable endoglucanase strain. After selection of potent fungal strain through extensive analysis, the endoglucanase was also produced in bioreactors and analysed for aflatoxins. The morphology of super Koji and A. oryzae mutant was also analysed through FESM.

\section{Process Development for Potent Koji Mutants Screening}

The process development for screening includes following steps;

\section{$1^{\text {st }}$ Screening: Hyper production of Endoglucanase (CMCase) on SFGM}


The control super Koji (A. oryzae) and 52 A. oryzae mutants were grown on SFGM containing $1 \%$ Carboxy-methyl cellulose (CMC) digested the cellulose in the media and 17 mutants were selected for further studies on the basis of clearance zone index $(\mathrm{Cl})$. The $\mathrm{Cl}$ indexes were in the range of $2.625 \mathrm{~cm}$ to $20.5 \mathrm{~cm}$ indicating the smallest clearance zone produced by 60(1) mutant and largest clearance zone produced by $60(5)$ mutant. While the clearance zone produced by control Koji was $8.0 \mathrm{~cm}$ (Table S1).

\section{$2^{\text {nd }}$ Screening: Resistance to 2-deoxy-D-Glucose (Catabolite Repression)}

The 17 mutants selected were further screened on the basis of catabolite repression in the presence of 2deoxy-D-Glucose and 7 fungal mutants were selected for further study on the basis of clearance index (Cl). A. oryzae mutant 60(5) produced largest zone with $25.30 \mathrm{~cm}$ while the clearance zone of control Koji was $4.21 \mathrm{~cm}$ (Table 1 and Fig. 1).

Table 1: Clearing Zone Index for the Production of Endoglucanase by Super Koji (A.oryzae) Mutants on Agar Plates containing 2-Deoxy D-Glucose $(0.1 \%, \mathrm{w} / \mathrm{v})$ \& Triton X-100 $(0.3 \% \mathrm{v} / \mathrm{v})$

\section{$3^{\text {rd }}$ Screening: Hyper production of Endoglucanase (CMCase) on LFGM:}

The equal volume of wet cell mass i.e. $0.3 \mathrm{~g}(\mathrm{w} / \mathrm{v})$ of inoculum of parental strain and 7 mutants were transferred in to the liquid fungal growth media. Total enzyme units, amount of protein and specific activity of endoglucanase were calculated under submerged fermentation. It was observed that all mutants were producing more endoglucanase than parental super Koji except $A$. oryzae mutant 100(6), which produced the enzyme equivalent to parental strain. Among mutants highest units of endoglucanase were produced by $A$. oryzae mutant $60(5)$ with $6.02 \mathrm{U} \mathrm{ml}^{-1}$ which was 3.6 folds greater than parental strain $\left(1.67 \mathrm{U} \mathrm{ml}^{-1}\right)$. The specific activity of mutant $60(5)$ was $170.93 \mathrm{U} \mathrm{mg}^{-1}$ and was 5.3 folds higher than the control Koji (32.2 $\left.\mathrm{U} \mathrm{mg}^{-1}\right)$ (Table 2 and Fig. 2).

Table 2: Production of Endoglucanase by 2-Deoxy D-Glucose Resistant Mutant Derivatives of Super Koji (A. oryzae) Grown under Submerged Conditions on Carboxymethylcellulose (CMC)

\section{$4^{\text {th }}$ Screening: Hyper Thermostability of Endoglucanase}

The half-life $\left(\mathrm{t}^{1} / 2\right)$ of endoglucanase produced by parental super Koji ( $A$. oryzae) and seven $A$. oryzae mutants at $55 \mathrm{C}$ and $60 \mathrm{C}$ was determined by applying pseudo first order plots (Fig. 3). The endoglucanase produced by $A$. oryzae mutant 60(5) was more thermostable among all fungal mutants having half-lives of $29.42 \mathrm{~min}$ and $14.8 \mathrm{~min}$ at $55 \mathrm{C}$ and $60 \mathrm{C}$, respectively, followed by mutant $60(2)$ with half-lives of $26.34 \mathrm{~min} \& 12.8 \mathrm{~min}$; mutant 80 (4) with $14.25 \mathrm{~min} \& 12.60 \mathrm{~min}$ at $55 \mathrm{C}$ and $60 \mathrm{C}$, respectively. The endoglucanase produced by $A$. oryzae mutant 60(5) was 4 folds more stable than parental strain at $60 \mathrm{C}$ (3.68 min). The thermostability of endoglucanase produced by 120(3) was almost equivalent to parental strain at $60 \mathrm{C}(3.29 \mathrm{~min})$. However, the stability of other mutant strains reduced (Table 3). 


\section{FESEM analysis of Super Koji ( $A$. oryzae) and mutant strain 60(5)}

After extensive screening $A$. oryzae mutant 60(5) comparatively proved to be the potent producer of thermostable endoglucanase. The difference in morphology of $A$. oryzae mutant $60(5)$ and super Koji $(A$. oryzae) was assessed by Field Emission Scanning Electron Microscopy (FESEM) by taking the resolution of $A$. oryzae mutant 60(5) at x 2,200 and that of super Koji (A. oryzae) at x 2,500 (Fig. 4). It was observed that control Koji $\left(A\right.$. oryzae) was more fragile than the mutant strain and it can be concluded that $\gamma^{-}$ radiations increased the stiffness of the fungal mycelia.

\section{Toxin analysis on LC-MS}

The crude extract of endoglucanase produced by A. oryzae mutant 60(5) was analysed on LC-MS for toxin analysis and the scan was compared with the standards and already published scan of control. It was confirmed that mutant does not produce any aflatoxins (Fig. 5).

\section{Production of Endoglucanase (CMCase) in Fermenters}

The growth kinetics of control super Koji $(A$. oryzae) and mutant 60(5) was determined in $10 \mathrm{~L}$ fermenter and maximum units of endoglucanase were $319 \mathrm{U} \mathrm{dl}^{-1}$ and $913 \mathrm{U} \mathrm{mg}^{-1}$ after 56 and 48 hours of growth, respectively. The weight of pack wet cells was $110.5 \mathrm{~g} \mathrm{dl}^{-1}$ and $15.40 \mathrm{~g} \mathrm{dl}^{-1}$.Cell mass doubling time $\left(\mathrm{t}_{\mathrm{d}}\right)$ was 5.09 and 10.71 hours, whereas, specific growth rate $(\mu)$ was 0.136 and 0.064 hours, respectively. The yield coefficient with respect to cell mass $\left(Y_{p / x}\right)$ of parental strain was $3.0 \mathrm{Ug}^{-1}$ and specific rate of endoglucanase production $\left(q_{\mathrm{p}}\right)$ was $0.39 \mathrm{Ug}^{-1} \mathrm{~h}^{-1}$ while the yield coefficient with respect to cell mass $\left(\mathrm{Y}_{\mathrm{p} / \mathrm{x}}\right)$ of $A$. oryzae mutant $60(5)$ was $59 \mathrm{Ug}^{-1}$ and specific rate of endoglucanase production $\left(q_{p}\right)$ was $3.84 \mathrm{Ug}^{-}$ ${ }^{1} \mathrm{~h}^{-1}$ (Table 4 and Fig. 6). The Production of endoglucanase by mutant 60(5) was scaled up to $200 \mathrm{~L}$ fermenters with $0.2 \mathrm{~g} \mathrm{(w/v)}$ inoculum and $821 \mathrm{U} \mathrm{dl}^{-1}$ were produced with cell mass doubling time of 8.42 h; specific growth rate of 0.82 hours; product yield coefficient with respect to cell mass was $89 \mathrm{U} \mathrm{g}^{-1}$ and specific growth rate was $7.37 \mathrm{U} \mathrm{g}^{-1} \mathrm{~h}^{-1}$ (Table 5).

Table 4: Kinetics of CMCase Production by Mutant Derivative of Super Koji ( $A$. oryzae) in 10L Fermenter under Submerged Condition on Raw Maize Starch $(2 \% \mathrm{w} / \mathrm{v})$ at $30^{\circ} \mathrm{C}$.

Table 5: Kinetics of Pilot Scale Production of CMCase in 200L Fermenter by Super Koji Mutant M-60(5) under Submerged Condition Grown on Raw Maize Starch $(2 \% \mathrm{w} / \mathrm{v})$ at $30^{\circ} \mathrm{C}$. 


\section{Discussion}

The fungi belonging to genus Aspergillus were considered as organism during year 1729 after the study of Micheli and 180 species of genus Aspergillus are present world-wide. A. oryzae and A.niger are generally recommended as safe (GRAS) and used for the commercial production of industrially important homologous and heterologous enzymes [32]. Higher concentration of endoglucanase was produced through improvement of fungal promoter having hyper expression system developed through expression cloning. The A. oryzae nia D300 strain was formed by expressing F1-carboxymethylcellulase ( $\mathrm{cmc} 1)$ gene of $A$. aculeatus in wild type $A$. oryzae RIB40 for enhancing the endoglucanase production to abundant level $[29,30]$. Recently, we have further improved the genetically modified $A$. oryzae RIB40 super Koji $(A$. oryzae) through random mutagenesis by treating with $0.60,0.80,1.00,1.20$ and $1.40 \mathrm{KGy}$ Y-radiations and generated 52 mutants based on at-least 3.0 log kill [31]. There are several other studies on fungal strain improvement for cellulase production. The genetic makeup and functions of an organism can be modified by random mutagenesis. [25] Genetically modified Trichoderma reesei through random mutagenesis by irradiating with Gamma rays frequency of 250 Gy produced by Co- 60 and UV. The mutants comparatively produced higher enzymes units than the parental strains. The radiations can cause changes in the base pairs or formation of pyrimidine dimers. [33] improved the A. niger through treatment of organism with 2KGy Gamma radiations and mutants were producing higher concentration of CMCase and FPAse activities than parental strain. The mutant strain was investigated to analyse the effect of Gamma radiations and found that the radiations induce polymorphism in the DNA analysed through PCR showing RAPD (Randomly amplified polymorphic DNA). In another study $A$. oryzae strains were improved by random mutagenesis for over produce of a-amylase and showed 6.73 and 5.13 times increase in dextrinizing and saccharogenic activities, respectively as compared to the parental strain [34].

Previously, we developed main stock of Koji mutants (52 strains) resistant to $1 \%(\mathrm{w} / \mathrm{v})$ Triton X-100 with the background thinking that the mutants may be having thermostable enzymes and successfully screened super Koji mutant M-100(6) with hyper production of thermostable amylases [31]. In the current study, we have screened the main stock of super Koji mutants for the potent Koji mutant having enhanced production of thermostable endoglucanases. Hence, after extensive screening selected $A$. oryzae mutant $60(5)$ through a process consisting of four steps. Triton X-100 an anionic detergent $(0.3 \%$ $\mathrm{w} / \mathrm{v}$ ) was used for the hindrance of fungal growth on agar plates for the screening of endoglucanase. The Triton X-100 has inhibitory effect on the growth of the fungal and bacterial cells by damaging the permeability of membranes, by retarding the access to the substrate and by increasing the solubility of hydrophobic substrates to a toxic level [35]. The organisms resistant to detergents will produce comparatively thermostable enzymes and can withstand harsh conditions in industrial bioprocess.

The A. oryzae mutants were qualitatively screened on the $1 \% \mathrm{CMC}$ in solid state cultures and endoglucanase quantity was evaluated by measuring the clearance zone index $(\mathrm{Cl})$. The $\mathrm{Cl}$ index was determined by making the zymographic analysis of CMCase and the plates were stained with Congo red dye overnight and then washed with $1 \mathrm{M} \mathrm{NaCl}$. The Congo red form visible complex with the Carboxymethyl Cellulose (CMC) and gives red colour. Because of the hydrolysis of cellulose into the 
monosaccharides and disaccharides, Congo red does not form complex and thus appeared as clearance zone or holo zone [36]. For the production of carbohydrates hydrolysing enzymes such as cellulases, xylanases by filamentous fungi, solid state fermentation system is suitable due to its intrinsic state and low cost [37].

In the next step of screening seventeen (17) A. oryzae mutants that were potent endoglucanase producers were screened in the presence of catabolite repressor (2-deoxy-D-glucose) and seven mutants were selected on the basis of clearance zone index. The maximum $\mathrm{Cl}$ was for mutant 60(5), hence was resistant to catabolic repressor. The resistance to catabolic repressor in mutant of $A$. oryzae is due to the presence of constitutive promotor [29]. Catabolic repression is the inhibition or repression of enzyme production by microbial cells in the presence of fermentable sugars such as glucose, glycerol etc. In Aspergillus, CreA is the catabolite repression protein, a zinc finger protein, which inhibit the expression of target genes in the presence of catabolite repressors [38]. The most potent enzyme producers can be selected on the basis of resistance to catabolic repressor (2-deoxy-D-glucose) and on the basis of rational selection techniques as random mutagenesis is the trial and error method [39]. [40] reported that the carbon source influenced the amount of hydrolytic enzymes and very low or trace amount of CMCase and xylanases from fungi were produced in the presence of glucose, cellubiose, lactose and glycerol due to catabolic repression while showed higher concentration in the presence of cellulose and xylan. In a study conducted by [41], selected the derepressed $A$. oryzae mutant for a-amylase resistant to antimetabolite 2-deoxy-D-glucose and selected the mutant isolates showed overproduction or unaltered concentration of enzyme in comparison to parental strain. The 2-deoxy-D-glucose has profound effects on the fungal growth and enzyme production as it affects the permeability of microbial membrane and affects the transportation of enzyme in to the media. In the study reported by [42]showed that the $A$. fumigatus was resistant to 2-deoxy-D-glucose up to a certain level and in the presence of $0.5 \mathrm{mg} \mathrm{ml}^{-1}$ catabolite repressor the CMCase, $\beta$-glucosidase and FPase activity was $13.2 \mathrm{U} \mathrm{ml}^{-1}, 28.9 \mathrm{U} \mathrm{ml}^{-1}$ and 21.3 $\mathrm{U} \mathrm{ml}^{-1}$, respectively. [43]Screened seven 2-deoxy-D-glucose resistant strains of Humicola insolens for cellulase production in submerged fermentation. The minimal concentration for 2-deoxy-D-glucose at which fungus used in the study was unable to grow was $0.3 \%$. Certain sugars such as D-cellobiose-1-5lactone, Cellobiose, sophorose (Di-saccharide) and lactones are the inducers of Cellulases [44, 45]. One of the possible mechanism for induction of cellulases production was reported is that after catalysis of cellulose by extracellular cellulases will produce soluble products that can enter the cells and induce the transcription of genes [46].

The potent endoglucanase producer can also be screened through specific activity that is inductive of the purity and specific type of enzyme produced in the submerged fermentation media. In the current study the endoglucanase specific activity was determined at regular interval, that is, by taken the sample of mutant $A$. oryzae grown in submerged culture after every 12 hours and the maximum endoglucanase activity (170.93 $\left.\mathrm{U} \mathrm{mg}^{-1}\right)$ was determined after 78 hours of incubation as compare to parental strain $\left(32.23 \mathrm{U} \mathrm{mg}^{-1}\right)$. Though the higher amount of protein was released by parental strain $\left(0.051 \mathrm{mg} \mathrm{ml}^{-1}\right)$ as compared to mutant $60(5)\left(0.035 \mathrm{mg} \mathrm{ml}^{-1}\right)$ showing the parental strain may produce different types of 
enzymes such as proteases, amylases, cellulase, etc but mutant 60(5) produced specifically more cellulase enzyme. Hence, the specific activity of mutant strain was 5.3 folds higher than parental strain. The results clearly indicate that the specific activity was enhanced due to random mutations, which may take place either in the regulatory region or either in the cellulase genes, therefore functionality of the enzyme was improved. The specific activity can also be improved because of changes in the electronegative environment and hydrogen bonding or loosening of buried cleft around the active site of the enzyme. All these changes can bring improvement in the catalytic activity of enzyme [47].

The temperature which cause loss in the catalytic activity of enzyme by distortion of primary and secondary structures of enzyme and thus alter the active site of enzyme is known as melting temperature $\left(T_{m}\right)$. The $T_{m}$ is the intrinsic property of enzyme and higher half-life $\left(t^{1} / 2\right)$ and melting temperature suggests that the enzyme is more thermostable at elevated temperatures in industries and can withstand for longer time without changing the structural and functional properties of enzyme [48]. The endoglucanase from mutant 60(5) was comparatively more thermostable as it showed $t \frac{1}{2}$ of 14.83 min at $60 \mathrm{C}$ which was 4 folds higher than parental strain. These results were also supported by study conducted by [30] and reported the t t1/20f endoglucanases from parental $A$. oryzae strain was 2 min at 56 C. However, the half-lives of endoglucanase isolated from Aspergillus fumigatus was comparatively higher with $t \frac{1}{2}$ of 6930,866 and $36 \mathrm{~min}$ at $60 \mathrm{C}, 70 \mathrm{C}$ and $80 \mathrm{C}$, respectively [9]. After incubating the enzyme at higher temperature for extended time and cooling, the irreversible unfolding and reversible inactivated state can be analysed by $T_{m}$ and $t^{1} 1 / 2[49]$.

Aflatoxin are mycotoxins and are harmful for both humans and animals due to their mutagenic, carcinogenic, immunosuppressive, hepatotoxic and genotoxic are the reported strains for aflatoxins include A. flavus, A. parasiticus, A. nominus, A. tamarii and A. pseudotamarii [50]. Studies also revealed the sequence similarity of $A$. flavus with the $A$. oryzae but $A$. oryzae is safe and does not produce any aflatoxins and therefore supplemented in food and feed [51]. The aflatoxins produced by Aspergillus species can be detected by molecular characterization of genes through PCR and through High Performance Liquid Chromatography (HPLC). The presence of mycotoxins in food and feed samples can be validated by Liquid chromatography-tandem mass spectroscopy (LC-MS/MS) [52]. In the current study the presence of aflatoxins were determined in endoglucanase produced by $A$. oryzae mutant $60(5)$ through LC-MS/MS and scans showed that the mutant strain does not produce any aflatoxin and is safe for industrial use in food and feed industry.

Random mutagenesis by gamma radiations also alter the morphology of $A$. oryzae mutant 60(5) and through Field emission scanning electron microscopy (FESM) it was analysed that the morphology of mutant 60(5) was more stiff and tough than parental strain. Therefore, the mutant strain can withstand harsh conditions in the industries without affecting the morphology of fungal mutant and can be potentially employed in food and feed industries.

Submerged fermentation is the widely used method for commercial production of cellulases due to the easy recovery of extracellular enzymes, although submerged fermentation can result in reduction of

Page 10/30 
enzyme activity and dilution of enzymes [53]. In the current study the A.oryzae mutant 60(5) was grown in $10 \mathrm{~L}$ fermenters under submerged conditions and maximum enzyme units obtained were $913 \mathrm{U} \mathrm{dl}^{-1}$ by using Raw Maize Starch as carbon source $(2 \% \mathrm{w} / \mathrm{v})$. The endoglucanase production by A.oryzae mutant

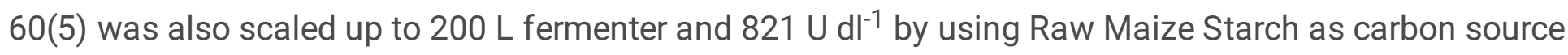
$(2 \% \mathrm{w} / \mathrm{v})$, which indicates that enzyme production is reproducible after being scaled up. The maximal endoglucanase production was due to the availability of nutrients in sufficient amount and the further decrease in the production of endoglucanase with time is because of depletion of macro and micro nutrients [22]. In one another study [54] studied the effect of different carbon sources such as Carboxymethyl cellulose, glucose, cellulose, sucrose and maltose on the production of endoglucanses from $A$. niger and better results were shown by cellulose and CMC.

\section{Conclusion}

We conclude that high ionizing radiation (Gamma ray) has induced potent mutations in super Koji mutant 60(5), which made it hyper producer of thermostable endoglucanase. The Koji mutant was resistant to catabolic repression and produced thermostable CMCase more specifically. The -rays made the Koji comparatively stiffer and did not trigger aflatoxins production. Improvements in thermostability and productivity of CMCases showed that -rays might have mutated the structural and regulatory genes of CMCases. Current report supports our previous findings regarding screening of mutants' and proved that our developed process is excellent for the screening of potent mutants. We consider our developed endoglucanase has great potential for applications in food and live-stock feed industries.

\section{Methodology}

\section{Stock of Koji (Aspergillus oryzae) Mutants}

The Koji mutants stock resistant to $1.0 \%$ Triton-X100, comprised of 52-strains, was obtained from Industrial Enzymes \& Biofuels Group, Industrial Biotechnology Division, National Institute for Biotechnology and Genetic Engineering (NIBGE), Faisalabad. The mutants stock was developed previously through random mutagenesis by exposing the super Koji fungus (Aspergillus oryzae $\mathrm{cmc} 1$ ) to $\mathrm{Y}$-rays of various exposure levels: $0.60,0.80,1.00,1.20 \& 1.40 \mathrm{KGy}$. The mutants were screened for the potent super Koji strain i.e. hyper producer of thermostable CMCases as described by [31].

\section{Fungal Growth Medium Composition}

The super Koji Aspergillus oryzae and its mutant derivatives (52 strains) were maintained on Solid Fungal Growth Medium (SFGM). The SFGM ingredients were gradually dissolved in about $800 \mathrm{ml}$ distilled water in already optimized concentration as mentioned below: $3 \mathrm{~g} \mathrm{NaNO}_{3}, 50 \mathrm{ml}$ Salt solution (\% w/v: $2.6 \% \mathrm{KCl}$, $\left.2.6 \% \mathrm{MgSO}_{4} \cdot 7 \mathrm{H}_{2} \mathrm{O}, 7.6 \% \mathrm{KH}_{2} \mathrm{PO}_{4}\right) ; 01 \mathrm{ml}$ Trace element solution (\% w/v: $0.11 \% \mathrm{Mo}_{7} \mathrm{O}_{24} \cdot 4 \mathrm{H}_{2} \mathrm{O}, 1.11 \%$ 
$\mathrm{H}_{3} \mathrm{BO}_{3}, 0.16 \% \mathrm{CoCl}_{2} .6 \mathrm{H}_{2} \mathrm{O}, 5 \%$ EDTA, 0.5\% $\mathrm{FeSO}_{4} .7 \mathrm{H}_{2} \mathrm{O}, 0.5 \% \mathrm{MnCl}_{2} .4 \mathrm{H}_{2} \mathrm{O}$ and $\left.2.2 \% \mathrm{ZnSO}_{4} .7 \mathrm{H}_{2} \mathrm{O}\right), 10 \mathrm{~g}$ glucose and $20 \mathrm{~g}$ agar. The $\mathrm{pH}$ of the medium was adjusted to $\mathrm{pH} 6.5$ by $1 \mathrm{M} \mathrm{NaOH} / \mathrm{HCl}$ [29]. After complete mixing of ingredients in $800 \mathrm{ml}$ distilled water, the volume of SFGM was raised up to one litre by adding distilled water.

For the production of enzyme, Liquid Fungal Growth Medium (LFGM) was prepared and like SFGM, the same concentration of salt and trace elements was added in LFGM; whereas, $1 \%(\mathrm{w} / \mathrm{v})$ Polypeptone and $10 \mathrm{mM}$ ammonium tartarate were used as nitrogen source instead of $\mathrm{NaNO}_{3}$ and $6.5 \mathrm{pH}$ of the medium was maintained. The $A$. oryzae and different mutant strains were grown on glucose as carbon source ( $2 \%$ $\mathrm{w} / \mathrm{v}$ ) and incubated at $30^{\circ} \mathrm{C}$ with shaking speed $150 \mathrm{rpm}$.

\section{Culture Maintenance}

The SFGM plates and slants were used for the maintenance of control Koji ( $A$. oryzae) strain and its fiftytwo mutants, which were then stored at $4^{\circ} \mathrm{C}$. For the preparation of media, $250 \mathrm{ml}$ Erlenmeyer flasks were taken, and $80 \mathrm{ml}$ distilled water was added to each flask, then separately weighed media ingredients were added and properly mixed to each flask. After adjusting the required $\mathrm{pH}$ (6.5), the volume of the SFGM was raised to $100 \mathrm{ml}$ by adding distilled water. Each Erlenmeyer flask was plugged with cotton and covered with aluminum foil to further reduce the chances of contamination. Moreover, 8-10 ml of SFGM was also poured per screw capped test tubes for the slant preparation and their caps were slightly loosened during autoclaving. Then the media was autoclaved at $121 \mathrm{C}$ for 15 minutes and $30 \mathrm{psi}$. After sterilization, the flasks were allowed to cool at room temperature, and then approximately $20-25 \mathrm{ml}$ of SFGM was poured into sterilized Pyrex glass Petri plates under sterilized condition. The plates were then allowed to solidify and in order to check contamination; the solidified plates were kept for one day at room temperature. Similarly, caps of the test tubes were tightened after autoclaving inside the autoclave and then laid in slanting position for the solidification. Afterwards, the SFGM plates \& slants were inoculated aseptically by loop full of super Koji $A$. oryzae and its mutants. The plates were sealed properly with paraffin after inoculation and then incubated for 12 to 15 days at $30 \mathrm{C}$ till the proper growth of fungal strains (formation of yellow spores). The fungal plates \& slants were stored at $4 \mathrm{C}$ and the cultures were refreshed once a month.

\section{Inoculum Preparation}

For the preparation of inoculum, $250 \mathrm{ml}$ Erlenmeyer flasks were taken and separately weighed media ingredients of LFGM were added to the flasks containing $80 \mathrm{ml}$ distilled water. After the adjustment of required $\mathrm{pH}(6.5)$, the volume of the media was raised up to $100 \mathrm{ml}$. For the breaking of fungal mycelia, about 4-5 glass beads $(\varnothing 8.0 \mathrm{~mm})$, that were properly washed was also added to the flasks. The flasks were plugged with cotton and covered with aluminum foil and sterilized at $121 \mathrm{C}$ and $30 \mathrm{psi}$ for 15 minutes. The LFGM was then cooled at room temperature and afterwards inoculated with 2-3 loop-full of 
A. oryzae and its mutants under aseptic conditions. After the inoculation the LGFM was incubated at 30 C, $150 \mathrm{rpm}$ in orbital shaker for 36 hours [29].

\section{Estimation of Wet Cell Mass}

To transfer equal amount of innoculum to growth medium for the endoglucanase production, the cell mass density in the inocula of control Koji and its mutants was estimated. Wet cells weight or packed cell mass was estimated by taking the samples in triplicate in $2 \mathrm{ml}$ capacity Eppendorf tubes that were already weighed. The inoculum was recovered by $1 \mathrm{ml}$ autoclaved micropipette tips (Tips were cut to pick fungal cells easily), the samples were centrifuged at 14,000 rpm for $15 \mathrm{~min}$ in order to separate the cells from the media. The supernatant was discarded, and wet cells weight was determined.

\section{CMCase Plate Assay and Clearing Zone Index (Cl):}

The endoglucanase (CMCase) hyper producing $A$. oryzae mutants were screened by plate assay. The super Koji ( $A$. oryzae) strain and its mutants were inoculated by sterilized tooth picks in the center of SFGM plates having pH 6.5, containing CMC $(1 \% \mathrm{w} / \mathrm{v})$ and Triton-X100 $(0.3 \% \mathrm{v} / \mathrm{v})$ for restriction of colony. The inoculated Petri plates were incubated at $30^{\circ} \mathrm{C}$ for comparable duration (8 days) and analyzed for clearing zone formation, indicating that the CMCase enzyme produced extra cellularly has hydrolyzed the CMC. Moreover, CMCase activity was confirmed by using Congo red staining method as described [55]. The plates were stained overnight with Congo red dye solution ( $1 \% \mathrm{w} / \mathrm{v}: 1 \mathrm{~g}$ Congo red was dissolved in $90 \mathrm{ml}$ distilled water and volume made up to $100 \mathrm{ml}$ ) and then washed (2-3 times) with $1 \mathrm{Molar} \mathrm{NaCl}$ solution for de-staining. The un-digested $\mathrm{CMC}$ remained red while clear zone appeared where hydrolysis of CMC occurred. The diameter of the clearing zone and fungal colony was measured at two dimensions. The clearing zone index was measured by the formula presented by [31].

[The Clearing zone index can be found in the supplemental files. Formula 1 in the Formulas document]

\section{Endoglucanase (CMCase) Activity}

CMCase activity was determined by adding appropriate amount of enzyme $(0.1 \mathrm{ml})$ in $1 \mathrm{ml}$ of Carboxymethylcellulose sodium salt ( $1 \% \mathrm{w} / \mathrm{v}$, as a substrate) and incubated at $45^{\circ} \mathrm{C}$ for $45 \mathrm{~min}$ in the presence of $1 \mathrm{ml}$ of $50 \mathrm{mM}$ sodium acetate buffer $\mathrm{pH}$. The reaction was quenched by placing the tubes in boiling water for $5 \mathrm{~min}$. The amount of reducing sugars released due to action of endoglucanase was determined by using the DNS assay [31]. Briefly, $1 \mathrm{ml}$ of 3,5 dinitrosalicyclic acid (DNS) reagent was added to $0.5 \mathrm{ml}$ of quenched reaction mixture (QRM) and the volume was raised up to $2 \mathrm{ml}$ with distilled water, then boiled for 10 minutes. Afterwards, change in absorbance $\left(A^{\circ}\right)$ was measured at $550 \mathrm{~nm}[30]$. Glucose standard factor was determined from the glucose standard curve and was $0.835 \mu$ mole. 
One unit of endoglucanase activity was defined as the amount of enzyme required to release $1 \mu \mathrm{mol}$ of reducing groups (calculated as glucose equivalents) $\min ^{-1}$ from $\mathrm{CMC}$ at $45^{\circ} \mathrm{C}, \mathrm{pH}$. The activity units were calculated by using the formula:

[The Activity Units can be found in the supplemental files. Formula 2 in the Formulas document]

\section{Protein Estimation}

The extracellular protein was estimated by method described by Bradford and using Bovine Serum albumin as a standard [56].

\section{Screening of Koji Mutants for Hyper Production of Thermostable CMCase}

The main stock of super Koji mutants (fifty two)was screened for the potent Koji strain having hyper production of thermostable endoglucanase was based on the following steps:

\section{$1^{\text {st }}$ Screening: Hyper production of Endoglucanase on SFGM}

The main stock of Koji mutants (total= 52), resistant to $1 \%$ Triton X-100, was screened for the potent mutants i.e. hyper producer of endoglucanase and grown on SFGM agar plates supplemented with $1 \%$ $(\mathrm{w} / \mathrm{v}) \mathrm{CMC}$ and $0.3 \%(\mathrm{v} / \mathrm{v})$ Triton $\mathrm{X}-100$ as colony restrictor. The plates were incubated at $30{ }^{\circ} \mathrm{C}$ for 8 days; stained with Congo red dye and to de-stain $1.0 \mathrm{M} \mathrm{NaCl}$ solution was used. The digested $\mathrm{CMC}$ appeared as white zone on the zymograph, while undigested remained red. Subsequently, diameters of the colony and clearing zones were measured at right angles and means were taken. Afterwards, $\mathrm{Cl}$ for CMCase activity was determined as described earlier.

\section{$2^{\text {nd }}$ Screening:Resistance to 2-deoxy-D-Glucose (Catabolite Repression)}

The potent CMCase hyper producer mutants selected through preliminary screening were then grown on SFGM agar plates containing (w/v): 1\% CMC, 0.2\% 2-deoxy-D-Glucose (2DOG) and 0.3\% Triton X-100 [42]. Afterwards, measuring the $\mathrm{Cl}$ for endoglucanase, the 2DOG resistant Koji mutants were selected on the basis of highest $\mathrm{Cl}$.

\section{$3^{\text {rd }}$ Screening:Hyper Production of Endoglucanase on LFGM}

The 2DOG resistant Aspergillus oryzae mutants were further screened under submerged growth conditions on the basis of endoglucanase hyper production. The inoculums of selected mutants were prepared and wet cell mass was determined as discussed earlier. For the production of enzyme, $100 \mathrm{ml}$ LFGM was prepared in $250 \mathrm{ml}$ Erlenmeyer flasks containing $2 \%(\mathrm{w} / \mathrm{v}) \mathrm{CMC}$, pH 6.5 and $4-5$ glass beads were added to each flask for breaking of fungal mycelia. The flasks were plugged with cotton and 
aluminum foil and autoclaved at $121 \mathrm{C}, 30 \mathrm{psi}$ for $20 \mathrm{~min}$. Then equal amount of inoculum $(0.292 \mathrm{~g}$ pack cells $\mathrm{dl}^{-1}$ ) of the mutants were transferred to the flasks containing LFGM and the batch cultures were grown for 96 hours at $30 \mathrm{C}, 150 \mathrm{rpm}$. Time course aliquots were taken at various time intervals and centrifuged at 14,000 rpm at $4 \mathrm{C}$ for 5 minutes. The supernatants were separated and analyzed for endoglucanase activity and total proteins. The mutants having higher enzyme production and specific activity were selected for further studies.

\section{$4^{\text {th }}$ Screening: Hyper Thermostability of Endoglucanase}

Irreversible thermostability of endoglucanase produced by potent 2DOG resistant super Koji mutants was determined at $55^{\circ} \mathrm{C}$ and $60^{\circ} \mathrm{C}$ by incubating the enzyme for about 60 minutes. Aliquots of enzymes were taken out after various time intervals and cooled on ice immediately for minimum 30 minutes for the refolding of enzyme [57]. Afterwards assayed for endoglucanase activity and half-life was calculated by using formula after applying pseudo first order plot:

[The half life formula can be found in the supplemental files. Formula 3 in the Formulas document]

The potent 2DOG resistant Koji mutants having highest endoglucanase productivity, specific activity and thermostability were finally selected for further studies.

\section{FESEM Analysis of Super Koji}

The fungal mycelia (cell mass) of both parental and mutated super Koji 60(5) strains was recovered by centrifuging one $\mathrm{ml}$ each of the inoculum for $5 \mathrm{~min}$ at 14,000 rpm. The cell mass was then mixed in 600 $\mu l$ fixative and gently shook for about $5-10$. Then incubated for 45 minutes at $4{ }^{\circ} \mathrm{C}$. Afterwards, centrifuged for 5 min at 4,000 rpm, the supernatant was discarded, and the cells were coated on stub with carbon. Then the cells attached on carbon stub were viewed under Field Emission Scanning Electron Microscope (FESEM) JEOL JSM7500F with different resolutions.

\section{Toxin analysis on LC-MS}

\section{Sample preparation}

The A. oryzae mutant 60(5) was grown in LFGM in submerged conditions and crude extract or cell free supernatant was extracted by mixing with equal volume of chloroform in separating funnel. Then by using rotary evaporator, chloroform was evaporated, and the residues left behind were dissolved in $2 \mathrm{ml}$ of methanol organic solvent. The mixture (Residues and Methanol) were then filtered through nylon membrane (Millipore) having pore size of $0.45 \mu \mathrm{m}$ and then aflatoxin was analysed by Quadrupole Linear Ion Trap Mass Spectrometer Finnegan LTQ XL hyphenated with Surveyor Plus LC system (LC-MS) manufactured by Thermo Fisher Scientific, USA. 


\section{Analysis of LC-MS}

The sample after preparation was then loaded by direct syringe pump electro spray ionization probe (ESI) and analyzed for Aflatoxins through LC/MS as prescribed method [58] with some modifications such as by keeping the capillary temperature $335^{\circ} \mathrm{C}$ and voltage $45 \mathrm{~V}, 5 \mathrm{kV}$ spray voltage, sheath gas flow rate and auxiliary gas flow rate of 70 and 20 arbitrary units, respectively. $10 \mathrm{ng} \mathrm{ml}^{-1}$ concentration of standard aflatoxins such as aflatoxin B1, B2, G1 and G2 were taken in separate acetonitrile tubes. Then by means of $10 \mu$ sample injection standard aflatoxins were loaded to auto-sampler and aflatoxin analytes from sample were separated by Surveyor Plus LC system (Thermo Fisher scientific) equipped with Luna ${ }^{\circledR} \mathrm{C}_{18}$ column (150 x $4.6 \mathrm{~mm} ; 3 \mu \mathrm{m}$ particle size, Phenomenex, USA) through chromatography. The mobile phase (methanol:acetonitrile:water in 22:22:56 v/v) was run for 20 min through the column having temperature of $30^{\circ} \mathrm{C}[31]$.

\section{Production of Endoglucanase (CMCase) in Fermenters}

Endoglucanase from $A$. oryzae mutant strain 60(5) was produced in $10 \mathrm{~L}$ and $200 \mathrm{~L}$ capacity fermenters by using Rafhan starch ( $2 \% \mathrm{w} / \mathrm{v})$ as carbon source, $30^{\circ} \mathrm{C}$ temperature, $6.5 \mathrm{pH}$ and $0.292 \mathrm{gm}$ and $0.2 \mathrm{gm}$ inoculum weights respectively [30]. The samples were taken after every 12 hours and analysed for endoglucanase activity, extracellular protein concentration and wet cell mass. Growth kinetics was also determined.

\section{Abbreviations}

A.oryzae: Aspergillus oryzae

Cl: Clearance Index

Y: Gamma

CMC: Carboxymethyl Cellulose

2DOG: 2-deoxy-D-Glucose

PCR: Polymerase Chain Reaction;

FESM: Field Emission Scanning Electron Microscopy

HPLC: High Performance Liquid Chromatography

LC-MS: Liquid Chromatography-Mass Spectroscopy

GRAS: Generally regarded as safe 
LFGM: Liquid Fungal Growth Medium

SFGM: Solid Fungal Growth Medium

QRM: Quenched Reaction Mixture

OD: Optical Density

t²:2: Half-life

$\mathrm{T}_{\mathrm{m}}$ : Melting Temperature

$A^{\circ}$ : Change in absorbance

DNS: Dinitrosalicyclic acid

\section{Declaration}

Acknowledgements:

This work is partially supported by Pakistan Atomic Energy Commission (PAEC) and National Institute for Biotechnology and Genetic Engineering (NIBGE). This work is also supported by Higher Education Commission (HEC) of Pakistan awarded project NRPU-6113.

Funding:

This Research did not receive any specific grant from funding agencies.

Availability of data and materials

All data generated or analyzed during this study are included in this published article and its supplementary information file.

Consent for publication

Not applicable.

Ethics approval and consent to participate

Not applicable.

Competing interests

We declare that there exists no competing interest.

Authors Contribution 
NZ carried out the lab work along and data analysis with the writing of manuscript. MHR designed the Research project and carried out data analysis and revision of project. BA carried out research work and data analysis. FI and AS helped in collecting samples from 200L fermenters. HA analysed the data. SR, BF and HS helped in formatting, data analysis and citation. WSK carried out FESM of fungal strains. The final manuscript is read and approved by all authors.

Author's Information

Ms. Neelam Zeb is enrolled in PhD in National Institute for Biotechnology and Genetic Engineering (NIBGE), Faisalabad, Pakistan affiliated with Pakistan Institute for Engineering and Applied Sciences (PIEAS), Islamabad, Pakistan. This manuscript is part of her PhD Research Project.

\section{References}

1. Choi JM, Han SS, Kim HS. Industrial applications of enzyme biocatalysis: Current status and future aspects. Biotechnol Adv. 2015;33(7):1443-1454.

2. Li X, Zhang Z, Song J. Computational enzyme design approaches with significant biological outcomes: progress and challenges. Comput Struct Biotechnol J. 2012;2(3):e201209007.

3. Singh R, Kumar M, Mittal A, Mehta PK. Microbial enzymes: industrial progress in 21st century. 3 Biotech. 2016;6(2):174.

4. Anbu P, Gopinath SC, Cihan AC, Chaulagain BP. Microbial enzymes and their applications in industries and medicine. Biomed Res Int. 2013;2013.

5. Nigam P. Microbial enzymes with special characteristics for biotechnological applications. Biomolecules. 2013;3(3):597-611.

6. van den Brink J, de Vries RP. Fungal enzyme sets for plant polysaccharide degradation. Appl Microbiol Biotechnol. 2011;91(6):1477.

7. Tariq R, Ansari I, Qadir F, Ahmed A, Shariq M, Zafar U, Ahmad A, Khan SA, Sohail M. Optimization of endoglucanase production from thermophilic strain of Bacillus licheniformis RT-17 and its application for saccharification of sugarcane bagasse. Pak J Bot. 2018;50(2):807-816.

8. Sajith S, Sreedevi S, Priji P, Unni KN, Benjamin S. Production and partial purification of cellulase from a new isolate, Penicillium verruculosum BS3. Br Microbiol Res J. 2015;9.

9. Saqib AA, Farooq A, Iqbal M, Hassan JU, Hayat U, Baig S. A thermostable crude endoglucanase produced by Aspergillus fumigatus in a novel solid state fermentation process using isolated free water. Enzyme Res. 2012;2012. 
10. El-Ghonemy DH, Ali TH, El-Bondkly AM, Moharam ME-S, Talkhan FN. Improvement of Aspergillus oryzae NRRL 3484 by mutagenesis and optimization of culture conditions in solid-state fermentation for the hyper-production of extracellular cellulase. Antonie Van Leeuwenhoek. 2014;106(5):853-864.

11. Karmakar M, Ray R. Current trends in research and application of microbial cellulases. Res J Microbiol. 2011;6(1):41-53.

12. Sreena C, Sebastian D. Augmented cellulase production by Bacillus subtilis strain MU S1 using different statistical experimental designs. Genet Eng Biotechnol J. 2018;16(1):9-16.

13. Murad H, Azzaz H. Cellulase and dairy animal feeding. J Biotechnol. 2010;9(3):238-256.

14. Wu B, Zheng S, Pedroso MM, Guddat LW, Chang S, He B, Schenk G. Processivity and enzymatic mechanism of a multifunctional family 5 endoglucanase from Bacillus subtilis BS- 5 with potential applications in the saccharification of cellulosic substrates. Biotechnol Biofuels. 2018;11(1):20.

15. Shajahan S, Moorthy IG, Sivakumar N, Selvakumar G. Statistical modeling and optimization of cellulase production by Bacillus licheniformis NCIM 5556 isolated from the hot spring, Maharashtra, India. J King Saud Univ Sci. 2017;29(3):302-310.

16. Gupta C, Jain P, Kumar D, Dixit A, Jain R. Production of cellulase enzyme from isolated fungus and its application as efficient refining aid for production of security paper. Int J Appl Microbiol Biotechnol Res. 2015;311-19.

17. Olanbiwoninu AA, Odunfa SA. Production of Cellulase and Xylanase by Aspergillus terreus KJ829487 Using Cassava Peels as Subtrates. Adv Microbiol. 2016;6(07):502.

18. Danmek K, Intawicha P, Thana S, Sorachakula C, Meijer M, Samson R. Characterization of cellulase producing from Aspergillus melleus by solid state fermentation using maize crop residues. Afr J Microbiol Res. 2014;8(24):2397-2404.

19. Hu H, Van den Brink J, Gruben B, Wösten H, Gu J-D, De Vries R. Improved enzyme production by cocultivation of Aspergillus niger and Aspergillus oryzae and with other fungi. Int Biodeterior Biodegradation. 2011;65(1):248-252.

20. Pirota R, Tonelotto M, Delabona P, Fonseca R, Paixão D, Baleeiro F, Bertucci Neto V, Farinas C. Bioprocess developments for cellulase production by Aspergillus oryzae cultivated under solid-state fermentation. Braz J Chem Eng. 2016;33(1):21-31.

21. Hirayama K, Watanabe H, Tokuda G, Kitamoto K, Arioka M. Purification and characterization of termite endogenous $\beta-1$, 4-endoglucanases produced in Aspergillus oryzae. Biosci Biotechnol Biochem. 2010;74(8):1680-1686. 
22. Mrudula S, Murugammal R. Production of cellulase by Aspergillus niger under submerged and solid state fermentation using coir waste as a substrate. Braz J Microbiol. 2011;42(3):1119-1127.

23. Sher H, Faheem M, Ghani A, Mehmood R, Rehman H, Bokhari SA. Optimization of cellulase enzyme production from aspergillus oryzae For industrial applications. World J Biol Biotechnol 2017;2(2):155158.

24. Vu VH, Pham TA, Kim K. Fungal strain improvement for cellulase production using repeated and sequential mutagenesis. Mycobiology. 2009;37(4):267-271.

25. Shahbazi S, Ispareh K, Karimi M, Askari H, Ebrahimi M. Gamma and UV radiation induced mutagenesis in Trichoderma reesei to enhance cellulases enzyme activity. Int J Farming Allied Sci (IJFAS). 2014;3(5):543-554.

26. Kim SC, Kang SH, Choi EY, Hong YH, Bok JD, Kim JY, Lee SS, Choi YJ, Choi IS, Cho KK. Cloning and characterization of an endoglucanase gene from Actinomyces sp. Korean native goat 40 . Asian-australas J Anim Sci. 2016;29(1):126.

27. Kuhad RC, Gupta R, Singh A. Microbial cellulases and their industrial applications. Enzyme Res. $2011 ; 2011$.

28. Chand P, Aruna A, Maqsood A, Rao L. Novel mutation method for increased cellulase production. J Appl Microbiol. 2005;98(2):318-323.

29. Rashid MH, Javed MR, Kawaguchi T, Sumitani J-i, Arai M. Improvement of Aspergillus oryzae for hyperproduction of endoglucanase: expression cloning of $\mathrm{cmc}^{-1}$ gene of Aspergillus aculeatus. Biotechnol Lett. 2008;30(12):2165.

30. Javed MR, Rashid MH, Nadeem H, Riaz M, Perveen R. Catalytic and thermodynamic characterization of endoglucanase (CMCase) from Aspergillus oryzae cmc-1. Appl Biochem Biotechnol. 2009;157(3):483497.

31. Aleem B, Rashid MH, Zeb N, Saqib A, Ihsan A, Iqbal M, Ali H. Random mutagenesis of super Koji (Aspergillus oryzae): improvement in production and thermal stability of a-amylases for maltose syrup production. BMC Microbiol. 2018;18(1):200.

32. Stojanović J, Jakovljević V, Matović I, Gajović O, Mijušković Z, Nedeljković T. Influence of detergent on metabolic activity of fungi Aspergillus niger. Nat Sci. 2011;3(06):466.

33. Mostafa AA. Effect of gamma irradiation on Aspergillus niger DNA and production of cellulases enzymes. J Am Sci. 2014;10152-160.

34. Maresma BG, Castillo BG, Fernández RC, Silva ESd, Maiorano AE, Rodrigues MFdA. Mutagenesis of Aspergillus oryzae IPT-301 to improve the production of $\beta$-fructofuranosidase. Braz J Microbiol. 
2010;41(1):186-195.

35. Abu-Ghunmi L, Badawi M, Fayyad M, Detergents. Fate of Triton X-100 Applications on Water and Soil Environments: A Review. J Surfactants Deterg. 2014;17(5):833-838.

36. Gohel HR, Contractor CN, Ghosh SK, Braganza V. A comparative study of various staining techniques for determination of extra cellular cellulase activity on Carboxy Methyl Cellulose (CMC) agar plates. Int J Curr Microbiol App Sci. 2014;3261-266.

37. Saroj P, Manasa P, Narasimhulu K. Characterization of thermophilic fungi producing extracellular lignocellulolytic enzymes for lignocellulosic hydrolysis under solid-state fermentation. Bioresour Bioprocess. 2018;5(1):31.

38. Viniegra-González G, Favela-Torres E. Why solid-state fermentation seems to be resistant to catabolite repression? Food Technol Biotechnol. 2006;44(3):397-406.

39. Abdullah R, Ikram-ul-Haq I, Butt Z, Khattak MI. Random mutagenesis for enhanced production of alpha amylase by Aspergillus oryzae IIB-30. Pak J Bot. 2013;45(1):269-274.

40. Kobakhidze A, Asatiani M, Kachlishvili E, Elisashvili V. Induction and catabolite repression of cellulase and xylanase synthesis in the selected white-rot basidiomycetes. Ann Agrar Sci. 2016;14(3):169-176.

41. Azin M, Noroozi E. Random mutagenesis and use of 2-deoxy-D-glucose as an antimetabolite for selection of a-amylase-overproducing mutants of Aspergillus oryzae. World $\mathrm{J}$ Microbiol Biotechnol. 2001;17(7):747-750.

42. Das A, Paul T, Halder SK, Maity C, Das Mohapatra PK, Pati BR, Mondal KC. Study on regulation of growth and biosynthesis of cellulolytic enzymes from newly isolated Aspergillus fumigatus ABK9. Pol J Microbiol. 2013;62(1):31-43.

43. Mariyam I. Multistep mutagenesis for the over-expression of cellulase in Humicola insolens. Pak J Bot. 2011;43(1):669-677.

44. Lynd LR, Weimer PJ, Van Zyl WH, Pretorius IS. Microbial cellulose utilization: fundamentals and biotechnology. Microbiol Mol Biol Rev. 2002;66(3):506-577.

45. Sun X, Liu Z, Zheng K, Song X, Qu Y. The composition of basal and induced cellulase systems in Penicillium decumbens under induction or repression conditions. Enzyme Microb Technol. 2008;42(7):560-567.

46. Amore A, Giacobbe S, Faraco V. Regulation of cellulase and hemicellulase gene expression in fungi. Curr genomics. 2013;14(4):230-249. 
47. Chen X, Li W, Ji P, Zhao Y, Hua C, Han C. Engineering the conserved and noncatalytic residues of a thermostable $\beta-1,4$-endoglucanase to improve specific activity and thermostability. Sci Rep. 2018;8(1):2954.

48. Ku T, Lu P, Chan C, Wang T, Lai S, Lyu P, Hsiao N. Predicting melting temperature directly from protein sequences. Comput biol chem. 2009;33(6):445-450.

49. Shirke AN, Su A, Jones JA, Butterfoss GL, Koffas MA, Kim JR, Gross RA. Comparative thermal inactivation analysis of Aspergillus oryzae and Thiellavia terrestris cutinase: role of glycosylation. Biotechnol bioeng. 2017;114(1):63-73.

50. Lee KR, Yang SM, Cho SM, Kim M, Hong S-Y, Chung SH. Aflatoxin B1 Detoxification by Aspergillus oryzae from Meju, a Traditional Korean Fermented Soybean Starter. J Microbiol Biotechnol. 2017;27(1):57-66.

51. Kniemeyer O. Proteomics of eukaryotic microorganisms: The medically and biotechnologically important fungal genus Aspergillus. J Proteomics. 2011;11(15):3232-3243.

52. De Santis B, Debegnach F, Gregori E, Russo S, Marchegiani F, Moracci G, Brera C. Development of a LC-MS/MS method for the multi-mycotoxin determination in composite cereal-based samples. J Toxins. 2017;9(5):169.

53. Sahin S, Ozmen I, Bıyık H. Industrial Applications of Endoglucanase Obtained from Novel and Native Trichoderma atroviride. CHEM BIOCHEM ENG Q. 2016;30(2):265-278.

54. Gautam S, Bundela P, Pandey A, Awasthi M, Sarsaiya S. Effect of different carbon sources on production of cellulases by Aspergillus niger. J App Sci Env Sanitation (JASES). 2010;5(3):295-300.

55. Omojasola P, Jilani O. Cellulase production by Trichoderma longi, Aspergillus niger and Saccharomyces cerevisae cultured on waste materials from orange. Pak J Biol Sci. 2008;11(20):23822388.

56. Bradford MMJAb. A rapid and sensitive method for the quantitation of microgram quantities of protein utilizing the principle of protein-dye binding. Anal Biochem. 1976;72(1-2):248-254.

57. Torpenholt S, De Maria L, Olsson MH, Christensen LH, Skjøt M, Westh P, Jensen JH, Leggio LL. Effect of mutations on the thermostability of Aspergillus aculeatus $\beta-1,4$-galactanase. Comput Struct Biotechnol J. 2015;13256-264.

58. Zheng R, Xu H, Wang W, Zhan R, Chen W. Simultaneous determination of aflatoxin B 1, B 2, G 1, G 2, ochratoxin A, and sterigmatocystin in traditional Chinese medicines by LC-MS-MS. Anal Bioanal Chem. 2014;406(13):3031-3039. 


\section{Tables}

Table 1: Clearing Zone Index for the Production of Endoglucanase by Super Koji (A.oryzae) Mutants on Agar Plates containing 2-Deoxy D-Glucose $(0.1 \%, \mathrm{w} / \mathrm{v}) \&$ Triton X-100 $(0.3 \% \mathrm{v} / \mathrm{v})$

\begin{tabular}{|l|l|l|l|l|}
\hline $\begin{array}{l}\text { Sr. } \\
\text { No }\end{array}$ & Fungal strains & $\begin{array}{l}\text { Halo zone + Colony } \\
\text { diameter }(\mathbf{c m})\end{array}$ & $\begin{array}{l}\text { Colony } \\
\text { diameter } \\
\mathbf{( c m )}\end{array}$ & $\begin{array}{l}\text { Clearing zone } \\
\text { index }\end{array}$ \\
\hline 1 & $\begin{array}{l}\text { Super koji }(\text { Aspergillus } \\
\text { oryzae) }\end{array}$ & $6.75 \pm 0.37$ & $1.6 \pm 0.07$ & 4.21 \\
\hline 2 & Mutant 60(2) & $13.5 \pm 0.45$ & $0.6 \pm 0.022$ & 22.50 \\
\hline 3 & Mutant 60(5) & $7.6 \pm 0.35$ & $0.3 \pm 0.018$ & 25.30 \\
\hline 4 & Mutant 60(10) & $4 \pm 0.2$ & $0.4 \pm 0.020$ & 10.00 \\
\hline 5 & Mutant 80(3) & $3 \pm 0.15$ & $0.3 \pm 0.016$ & 10.00 \\
\hline 6 & Mutant 80(4) & $13.25 \pm 0.5$ & $1.0 \pm 0.019$ & 13.25 \\
\hline 7 & Mutant 80(7) & $6.75 \pm 0.22$ & $0.50 \pm 0.036$ & 13.50 \\
\hline 8 & Mutant 80(11) & $5.5 \pm 0.33$ & $0.5 \pm 0.025$ & 11.00 \\
\hline 9 & Mutant 100(2) & $2 \pm 0.11$ & $0.2 \pm 0.01$ & 10.00 \\
\hline 10 & Mutant 100(3) & $9.15 \pm 0.33$ & $0.5 \pm 0.015$ & 18.30 \\
\hline 11 & Mutant 100(6) & $6.5 \pm 0.40$ & $0.45 \pm 0.027$ & 14.40 \\
\hline 12 & Mutant 100(7) & $4 \pm 0.2$ & $0.4 \pm 0.02$ & 10.00 \\
\hline 13 & Mutant 100(8) & $8.5 \pm 0.55$ & $0.7 \pm 0.042$ & 12.10 \\
\hline 14 & Mutant 100(11) & $2.5 \pm 0.12$ & $0.2 \pm 0.011$ & 12.50 \\
\hline 15 & Mutant 100(12) & $3.75 \pm 0.2$ & $0.3 \pm 0.018$ & 12.50 \\
\hline 16 & Mutant 120(3) & $6.50 \pm 0.34$ & $0.35 \pm 0.01$ & 18.60 \\
\hline 17 & Mutant 140(2) & $2.5 \pm 0.15$ & & 12.50 \\
\hline
\end{tabular}

Clearance zone index $(\mathrm{CI})=$ (halo zone diameter + colony diameter $) /$ colony diameter. Data presented are average values $\pm S D$ of $n=3$ experiments.

Table 2: Production of Endoglucanase by 2-Deoxy D-Glucose Resistant Mutant Derivatives of Super Koji (A. oryzae) Grown under Submerged Conditions on Carboxymethylcellulose (CMC) 


\begin{tabular}{|l|l|c|c|c|}
\hline Sr. No & Fungal Strains & $\begin{array}{c}\text { Endoglucanase } \\
\left(\mathbf{U ~ m ~}^{-\mathbf{1}}\right)\end{array}$ & $\begin{array}{c}\text { Protein } \\
\left(\mathbf{m g ~ m}^{-1}\right)\end{array}$ & $\begin{array}{c}\text { Specific activity } \\
\left(\mathbf{U ~ m ~}^{-1} \mathbf{~}\right)\end{array}$ \\
\hline 1 & Parental Strain & $1.67 \pm 0.09$ & $0.051 \pm 0.003$ & 32.23 \\
\hline 2 & Mutant 60(2) & $3.36 \pm 0.25$ & $0.033 \pm 0.003$ & 100.70 \\
\hline 3 & Mutant 60(5) & $6.02 \pm 0.31$ & $0.035 \pm 0.003$ & 170.93 \\
\hline 4 & Mutant 80(4) & $2.67 \pm 0.13$ & $0.042 \pm 0.004$ & 63.339 \\
\hline 5 & Mutant 80(7) & $4.96 \pm 0.33$ & $0.041 \pm 0.005$ & 121.54 \\
\hline 6 & Mutant 100(3) & $4.99 \pm 0.36$ & $0.034 \pm 0.004$ & 144.64 \\
\hline 7 & Mutant 100(6) & $1.60 \pm 0.08$ & $0.043 \pm 0.002$ & 37.08 \\
\hline 8 & Mutant 120(3) & $5.07 \pm 0.29$ & $0.036 \pm 0.004$ & 141.56 \\
\hline
\end{tabular}

Data presented are average values \pm SD of $n=3$ experiments.

Table 3: Irreversible Thermostability of Endoglucanase from Potent 2-Deoxy D-Glucose Resistant Mutant Derivatives of Super Koji (A. oryzae) at $55^{\circ} \mathrm{C}$ and $60^{\circ} \mathrm{C}$

\begin{tabular}{|l|l|c|c|c|c|}
\hline Sr. No & g-Rays Exposure & \multicolumn{2}{|c|}{$\begin{array}{c}\boldsymbol{K}_{\mathbf{d}} \\
\left(\mathbf{m i n}^{-\mathbf{1}} \mathbf{)}\right.\end{array}$} & \multicolumn{2}{c|}{$\begin{array}{c}\text { Half Life (t]) } \\
\text { (min) }\end{array}$} \\
\cline { 3 - 6 } & & $\mathbf{5 5}^{\circ} \mathbf{C}$ & $\mathbf{6 0}{ }^{\circ} \mathbf{C}$ & $\mathbf{5 5}{ }^{\circ} \mathbf{C}$ & $\mathbf{6 0}{ }^{\circ} \mathbf{C}$ \\
\hline 1 & Super Koji (Control) & -0.07287 & -0.1880 & 9.5 & 3.7 \\
\hline 2 & Mutant-60(2) & -0.02631 & -0.0541 & 26.3 & 12.8 \\
\hline 3 & Mutant-60(5) & -0.02356 & -0.0467 & 29.4 & 14.8 \\
\hline 4 & Mutant-80(4) & -0.04863 & -0.0550 & 14.3 & 12.6 \\
\hline 5 & Mutant-80(7) & -0.19750 & -0.3039 & 3.5 & 2.3 \\
\hline 6 & Mutant-100(3) & -0.13250 & -0.3348 & 5.2 & 2.1 \\
\hline 7 & Mutant-100(6) & -0.07514 & -0.2725 & 9.2 & 2.5 \\
\hline 8 & Mutant-120(3) & -0.26780 & -0.2104 & 2.6 & 3.3 \\
\hline
\end{tabular}

$K_{\mathrm{d}}$ (first order rate constant of inactivation) determined from Fig. 3 , t (half-life) $=\ln 2 / K_{\mathrm{d}}=0.693 / K_{\mathrm{d}}$.

Table 4: Kinetics of CMCase Production by Mutant Derivative of Super Koji (A. oryzae) in 10L Fermenter under Submerged Condition on Raw Maize Starch (2\% w/v) at 30 ${ }^{\circ} \mathrm{C}$. 


\begin{tabular}{|c|c|c|c|c|c|c|c|}
\hline Strain & $\begin{array}{l}\text { CMCase (U d } \\
\text { 1) }\end{array}$ & $\begin{array}{l}\text { Protein } \\
\text { (mg dl- } \\
\text { 1) }\end{array}$ & $\begin{array}{l}\text { Cell } \\
\text { mass } \\
\left(\mathrm{g} \mathrm{dl}^{-1}\right)\end{array}$ & $\mu\left(\mathrm{h}^{-1}\right)$ & $t_{d}(h)$ & $\begin{array}{l}Y_{p / x} \\
\left(\begin{array}{l}U \\
1\end{array}\right)\end{array}$ & $\begin{array}{l}{ }_{\mathrm{p}} \\
\left(\mathrm{U}^{\mathrm{U}} \mathrm{g}^{-1} \mathrm{~h}^{-}\right.\end{array}$ \\
\hline $\begin{array}{l}\text { Koji } \\
\text { (Control) }\end{array}$ & 319 & 1.57 & 110.5 & 0.1361 & 5.09 & 3 & 0.39 \\
\hline Mutant-60(5) & 913 & 1.80 & 15.40 & 0.0647 & 10.71 & 59 & 3.84 \\
\hline
\end{tabular}

Where: $\mu$ (Specific growth rate) determined from Fig. 6; $\mathrm{t}_{\mathrm{d}}$ (Biomass doubling time) $=\ln 2 / \mu, Y_{p / \mathrm{x}}=$ Product yield coefficient with respect to cell mass; $q_{\mathrm{p}}$ (Specific rate of product formation) $=Y_{p / \mathrm{x}} \times \mu$

Table 5: Kinetics of Pilot Scale Production of CMCase in 200L Fermenter by Super Koji Mutant M-60(5) under Submerged Condition Grown on Raw Maize Starch (2\% w/v) at $30^{\circ} \mathrm{C}$.

\begin{tabular}{|c|c|c|c|c|c|c|c|}
\hline Strain & $\begin{array}{l}\text { CMCase ( } \mathrm{U} \mathrm{dl}^{-} \\
\text {1) }\end{array}$ & $\begin{array}{l}\text { Protein } \\
\text { (mg dl- } \\
\text { 1) }\end{array}$ & $\begin{array}{l}\text { Cell } \\
\text { mass } \\
\left(\mathrm{g} \mathrm{dl}^{-1}\right)\end{array}$ & $\mu\left(\mathrm{h}^{-1}\right)$ & $t_{d}(h)$ & $\begin{array}{l}Y_{\mathrm{p} / \mathrm{x}} \\
(\mathrm{U} g \\
\left.{ }_{1}\right)\end{array}$ & $\begin{array}{l}{ }_{p} \\
\left(\mathrm{U}^{-1} \mathrm{~g}^{-1}\right. \\
{ }^{-}\end{array}$ \\
\hline $\begin{array}{l}\text { Mutant- } \\
60(5)\end{array}$ & 821 & 5.67 & 9.175 & 0.08234 & 8.42 & 89 & 7.37 \\
\hline
\end{tabular}

Where: $\mu$ (Specific growth rate); $\mathrm{t}_{\mathrm{d}}$ (Biomass doubling time) $=\ln 2 / \mu, Y_{p / \mathrm{x}}=$ Product yield coefficient with respect to cell mass; $q_{\mathrm{p}}$ (Specific rate of product formation) $=Y_{p / \mathrm{x}} \times \mu$

Figures 

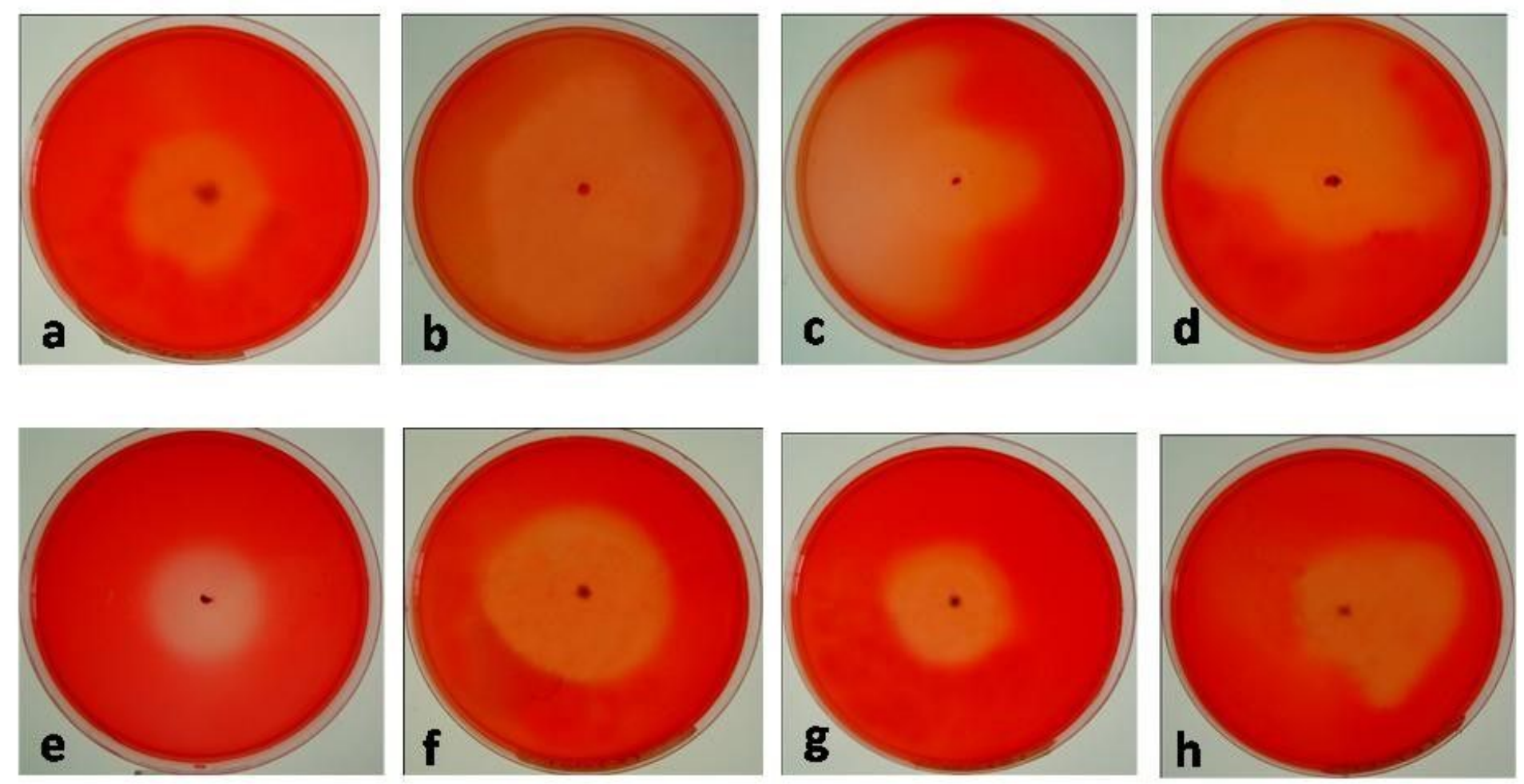

\section{Figure 1}

Endoglucanase production by mutant derivatives of super Koji (Aspergillus oryzae) on agar plates in the presence of 2-deoxy D-glucose (0.1\%w/v) \& 0.2\% Triton-X100. a. Control Koji, b. M-60(2), c. M-60(5), d. M80(4), e. M-80(7), f. M-100(3), g. M-100(6), h. M-120(3) 


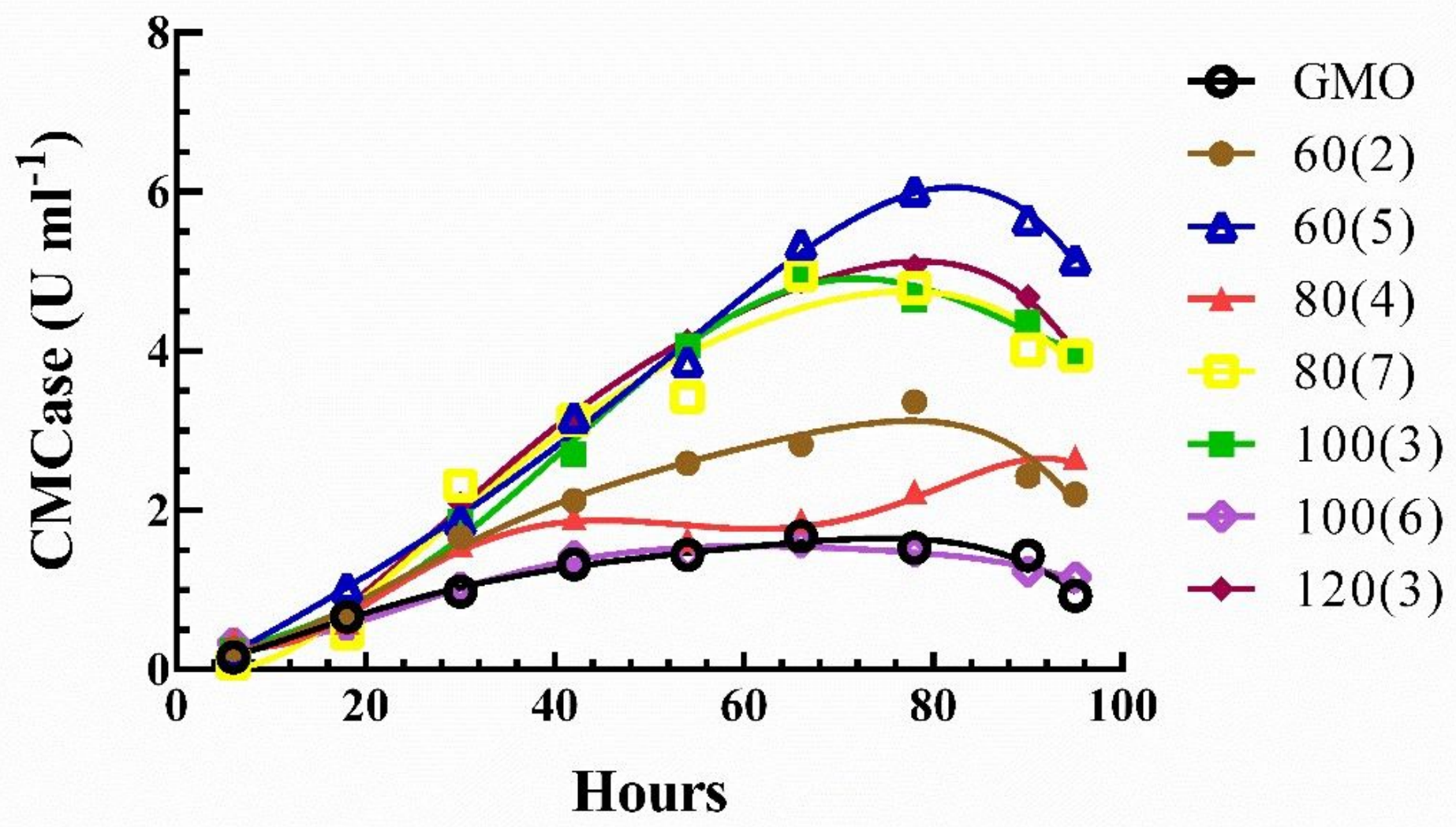

Figure 2

Endoglucanase production by mutant derivatives of super Koji (A. oryzae) resistant to 2-Deoxy D-Glucose under Submerged Conditions on Carboxymethyl cellulose (CMC) 

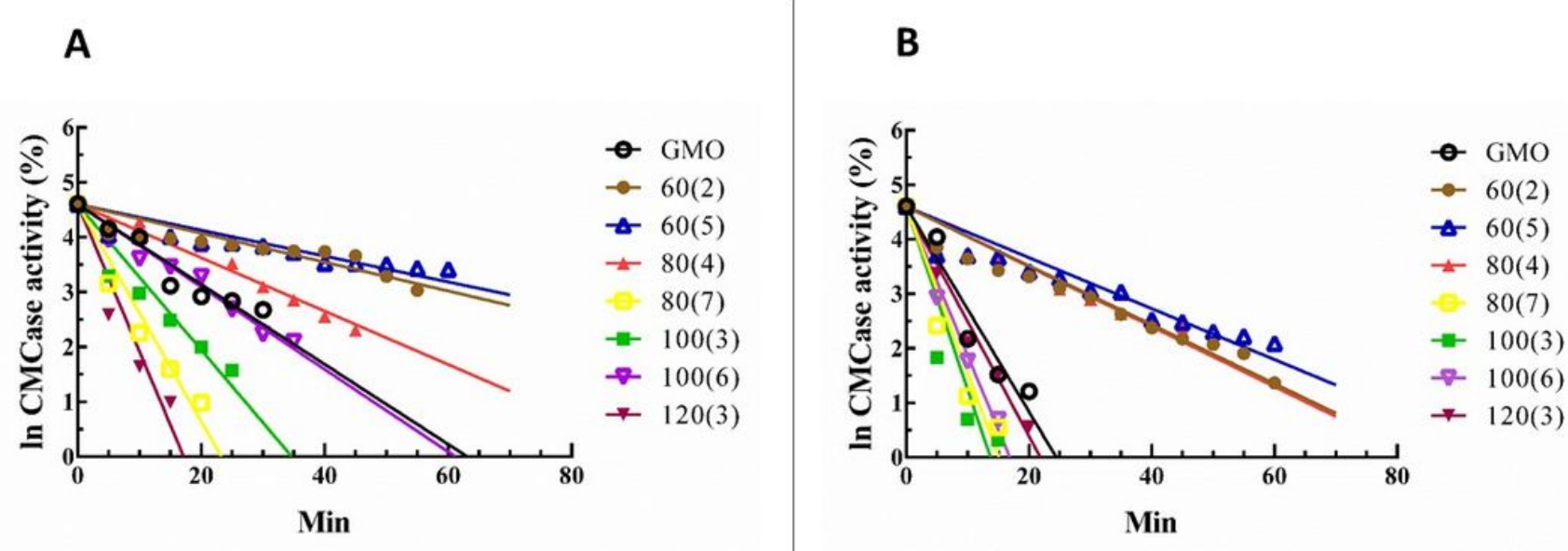

\section{Figure 3}

Pseudo first order plots for irreversible thermostability of endoglucanase from potent 2-deoxy D-glucose resistant mutant derivatives of super Koji (A. oryzae). A: $55^{\circ} \mathrm{C} \& \mathrm{~B}: 60^{\circ} \mathrm{C}$.
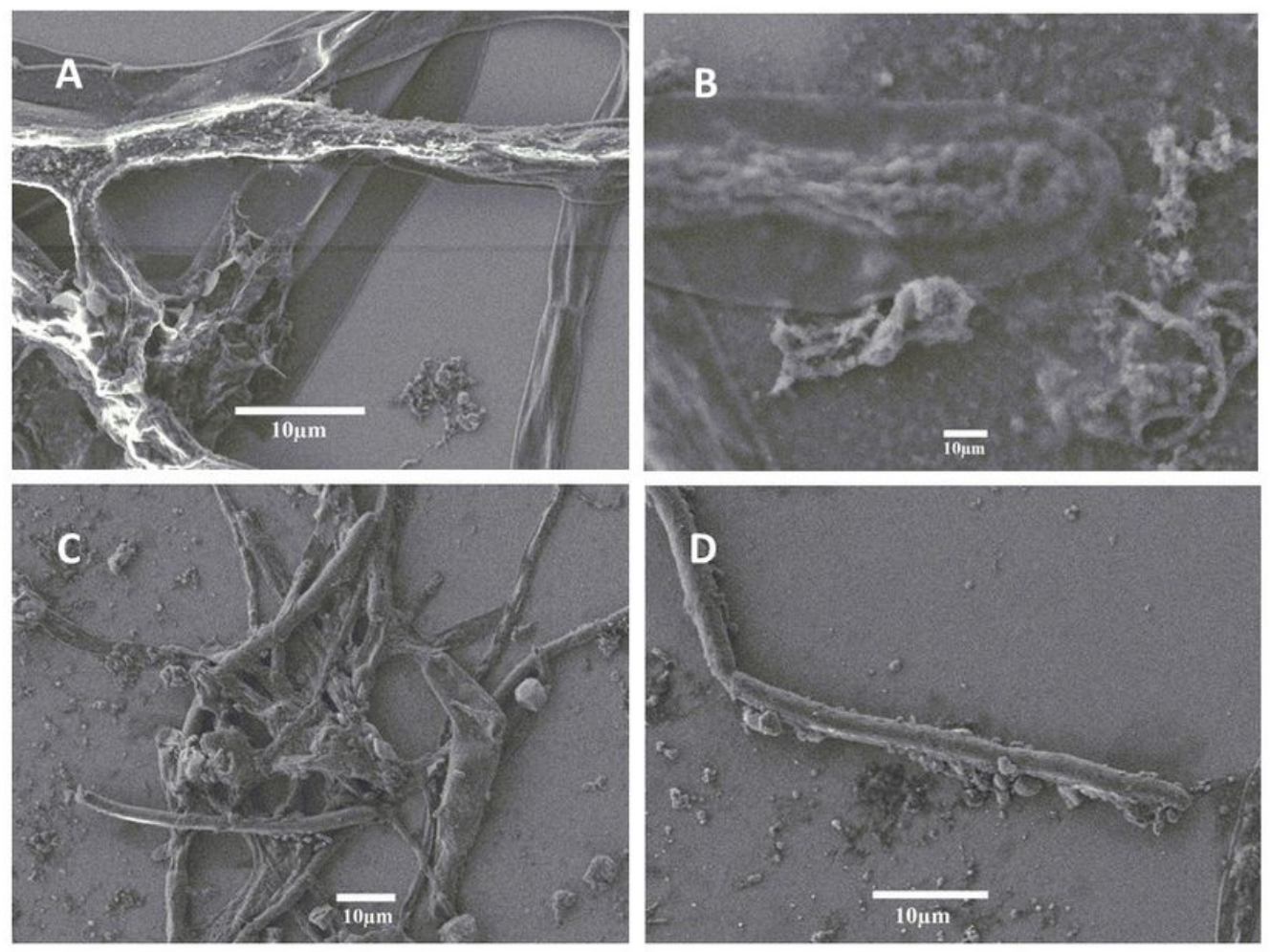


\section{Figure 4}

Field Emission Scanning Electron Microscopy (FESEM) of super Koji (A. oryzae). A: $\times 2500, B: \times 8000$ and mutant 60(5): C: $\times 1100, \mathrm{D}: \times 2200$

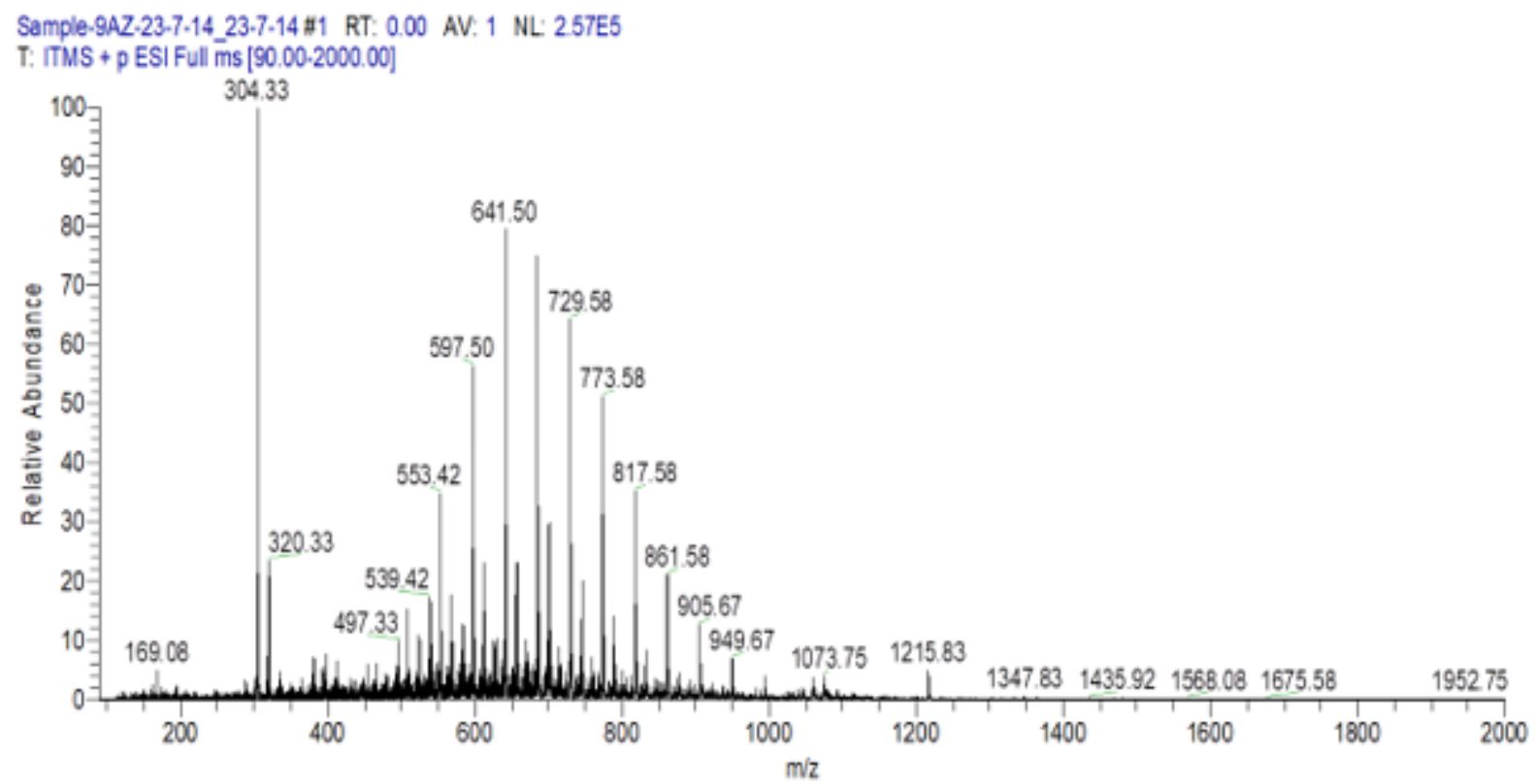

\section{Figure 5}

Aflatoxin analysis of Super Koji A. oryzae mutant 60(5) through LC-MS 


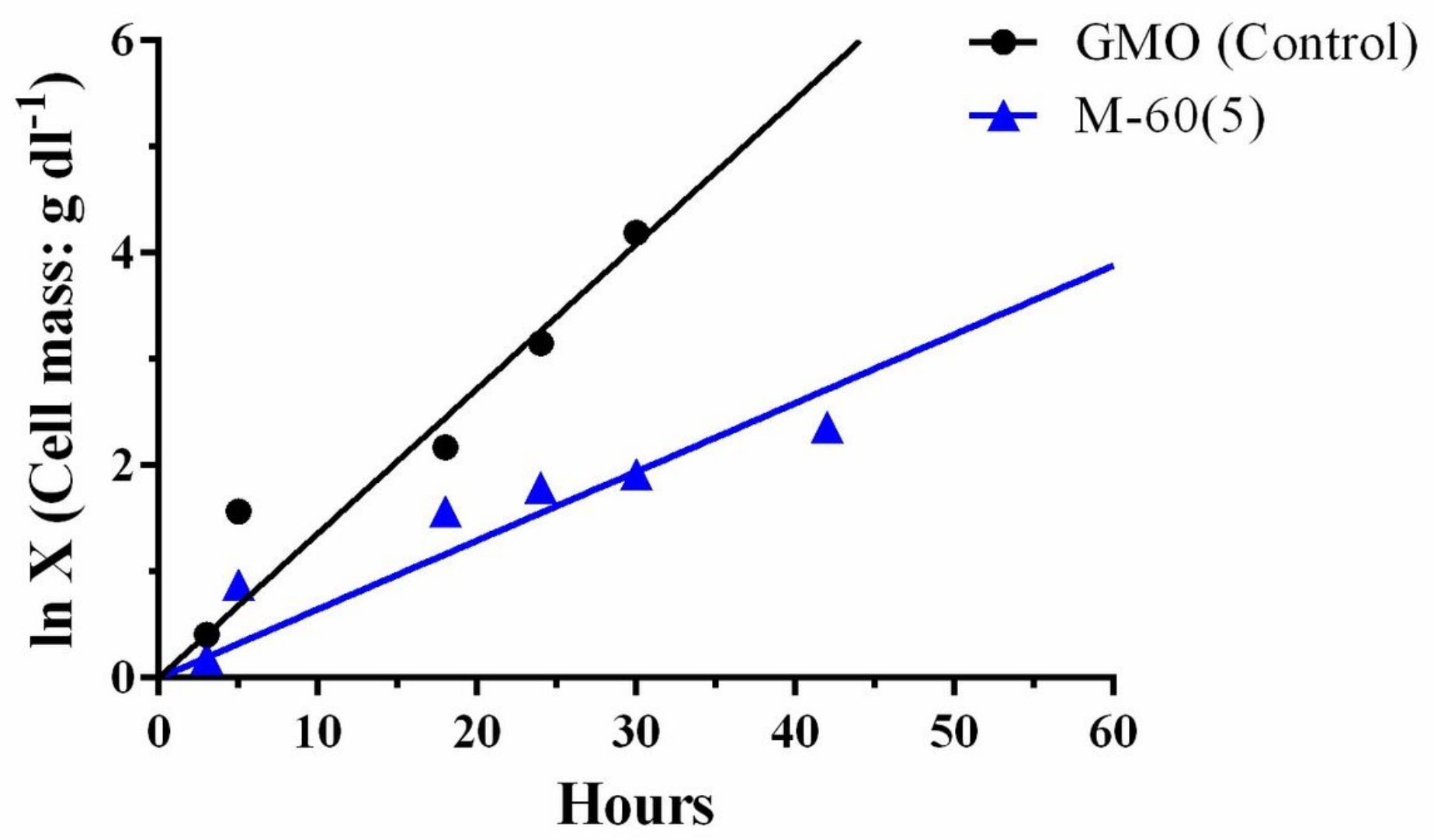

Figure 6

First order plot for the determination of specific rate of cell mass formation ( $\square$ ) by parental super Koji and its mutant 60 (5) in $10 \mathrm{~L}$ fermenter.

\section{Supplementary Files}

This is a list of supplementary files associated with this preprint. Click to download.

- AdditionalFile1.docx

- FormulaDocument.docx 